\title{
Peran Orang Tua dalam Pendampingan Belajar Anak di Masa Pandemi Covid-19
}

\author{
Novita Afkarina ${ }^{1}$, Fayruzah El-Faradis ${ }^{2}$ \\ Institut Dirosat Islamiyah Al-Amien Prenduan, Indonesia \\ ${ }^{1}$ afkavina@gmail.com, ${ }^{2}$ faradisviolet@gmail.com
}

\begin{abstract}
Abstrak
Tujuan dari penelitian ini adalah untuk mengetahui bagaimana kondisi orang tua yang kurang memahami teknologi dalam mendampingi belajar anak di masa pandemi covid serta bagaimana peran orang tua dalam pendampingan belajar anaknya di masa pandemi covid 19. Metode penelitian ini menggunakan metode penelitian kualitatif studi kasus. Subjek dalam penelitian ini adalah orang tua pada anak kelas 1-3 MI Mambaul Ulum desa Pakandangan Tengah. Pengumpulan data dengan wawancara, observasi, dan dokumentasi. Selanjutnya data analisis, meliputi tiga prosedur yaitu: (1) reduksi (2) penyajian data (3) penarikan kesimpulan. Hasil dari penelitian ini adalah 1) Orang tua yang kurang memahami teknologi merasa kesulitan dalam mendampingi belajar anak di masa pandemi covid 19 sehingga dalam pendampingan tersebut menjadi kurang optimal. 2) Adapun peran orang tua dalam mendampingi belajar anak yaitu, orang tua sebagai pendamping, sebagai motivator, fasilitator, tempat berdiskusi dan bertanya serta menciptakan lingkungan yang kondusif untuk belajar.
\end{abstract}

Kata Kunci: pandemi covid 19, pendampingan anak, peran orang tua

\footnotetext{
Abstract

The purpose of this research is to find out how to know the condition of parent who do not understand technology in accompanying their children's learning during covid 19 more over how is the role of parent in accompanying their children's learning during covid 19. This research method used qualitative
} 
on case study. The subjects in this study are parents in grade 13 MI Mambaul Ulum Desa Pakandangan Tengah. Data collection used are interview, observation and documentation. Then the data analysis includes three procedures, are: (1) data reduction (2) data presentation (3) conclusions. The result of this study are 1) parent who dot not understand technology and lack insight, find it difficult to accompany their children's learning during the covid 19 pandemic so that the assistance is less than optimal. 2) As for the important role of parent in accompanying children, parent as motivator, parent as fasilitator, as place to discuss and ask question, as well as creating an conducive environment to learning.

Keywords: accompanying children, the role of parents, the covid 19 pandemi

\section{PENDAHULUAN}

Dunia saat ini digemparkan dengan munculnya virus corona (covid-19) termasuk negara Indonesia. Virus ini pertama kali ditemukan di Wuhan China dan menyebar di seluruh dunia sehingga mengakibatkan kematian yang cukup banyak. Dampak dari virus ini bukan hanya mengancam kesehatan masyarakat akan tetapi ekonomi dan juga pendidikan.

Sejak corona menyebar di Indonesia pada awal bulan maret pemerintah segera mengambil kebijakan untuk mencegah penularan virus corona. Karena virus ini menyebar sangat cepat dan sudah banyak memakan korban jiwa di berbagai Negara, sehingga pemerintah melakukan tindakan dalam upaya untuk memutus rantai penyebaran virus corona salah satunya yaitu menerapkan pembelajaran jarak jauh (daring) baik dari tingkat dasar maupun tingkat perguruan tinggi.

Dengan kebijakan pembelajaran jarak jauh atau belajar di rumah, peran orang tua dalam mendampingi kesuksesan belajar anak selama di rumah menjadi sangat penting. Orang tua yang awalnya 
berperan membimbing sikap dan keterampilan yang mendasar, seperti pendidikan agama untuk patuh terhadap aturan, dan untuk pembiasaan yang baik, namun semenjak adanya virus covid-19 perannya menjadi meluas yaitu sebagai pendamping akademik. ${ }^{1}$ Tidak hanya itu dengan adanya kebijakan belajar di rumah menyebabkan peran orang tua dalam proses pembelajaran juga menjadi sangat vital. Berkaitan dengan peran orang tua dalam konsep belajar di rumah adalah orang tua membantu dalam mengembangkan potensi dan kreatifitas anak, sebagai motivator, fasilitator, pengawas dan sekaligus sebagai evaluator untuk anak-anaknya.

Mengingat pentingnya peranan orang tua dalam mendidik anak, penelitian-penelitian yang telah ada membuktikan bahwa orang tua memiliki andil yang sangat besar dalam kemampuan anak dalam lingkup pendidikan. Namun kenyataannya ada orang tua yang tidak bisa mendukung, karena kurang memahami dalam hal teknologi sehingga pengawasan atau pendampingan orang tua menjadi kurang maksimal. Dalam segi ekonomi juga yang terbatas karena tidak semua orang berpenghasilan cukup dalam seharinya-harinya apalagi di tengah wabah seperti saat ini. Banyak siswa yang masih belum mempunyai ponsel sehingga mereka harus numpang kepada temantemannya yang memiliki fasilitas yang lengkap untuk sistem pembelajaran ini. Bahkan ada juga untuk membeli kuota saja terkadang masih belum mampu. Dengan beberapa faktor tersebut juga bisa menghambat pembelajaran daring siswa.

Pandemi Covid telah mengakibatkan perubahan pola aktivitas manusia dalam kehidupan sehari-hari, salah satunya dalam kegiatan

\footnotetext{
${ }^{1}$ Euis Kurniawati and dkk, "Analisis Peran Orang Tua Dalam Mendampingi Anak Di Masa Pandemi Covid 19,” Jurnal Pendidikan Anak Usia Dini 5 (2021): 242.
} 
belajar. Konsep belajar di rumah telah dirumuskan dalam rangka mempertahankan kegiatan belajar mengajar di tengah pandemi mendunia ini. Konsep belajar di rumah adalah konsep belajar dimana rumah digunakan sebagai arena namun tidak mengabaikan peran orang tua dan guru. ${ }^{2}$ Jadi peran orang tua memang sangat penting, karena selain memantau perkembangan pendidikan pada anak juga harus bisa memotivasi anaknya untuk tetap semangat tidak hanya di masa pandemi atau saat pembelajaran daring saja melainkan juga setiap harinya.

Menurut anak-anak kelas 1-3 MI Mambaul Ulum ternyata masih ada sebagian dari orang tuanya yang tidak ikut membantu anak dalam menggunakan teknologi dalam sistem pembelajaran daring ini, Oleh karena itu peneliti tertarik untuk meneliti peran orang tua dalam pendampingan belajar anak kelas 1-3 MI Mambaul Ulum desa Pakandangan Tengah di masa pandemi covid-19.

Adapun sebagai bahan acuan peneliti, dicantumkan tulisan dan penelitian terdahulu yaitu, Penelitian yang pertama yaitu jurnal dari, Nika Cahyati dan Rita Kusumah, dengan judul: Peran Orang Tua dalam Menerapkan Pembelajaran di Rumah Saat Pandemi Covid 19. Hasil dari penelitian ini adalah orang tua dapat meningkatkan kelekatan hubungan dengan anaknya dan orang tua dapat melihat langsung perkembangan kemampuan anaknya dalam belajar. ${ }^{3}$

Penelitian yang kedua yaitu dari Agustien Lilawati, dengan judul: Peran Orang Tua Dalam Mendukung Kegiatan Pembelajaran Di Rumah Pada Masa Pandemi. Hasil penelitian ini menunjukkan

${ }^{2}$ Ketut Sudarsa and dkk, "Covid-19: Perspektif Pendidikan Yayasan," Kita Menulis, 32-33.

3 Nika Cahyati and Rita Kusumah, "Peran Orang Tua Dalam Menerapkan Pembelajaran Di Rumah Saat Pandemic Covid 19," Jurnal Golden Age Universitas Hamzanwadi 4 (2020): 152-159. 
bahwa peran orang tua terhadap penerapan pembelajaran di rumah pada masa pandemi dalam mendidik anak meliputi pendampingan dan sebagai motivator dan dampak peran orang tua terhadap pembelajaran pada masa pandemi di RA Team Cendikia Surabaya, orang tua memfasilitasi keterlibatan kegiatan pembelajaran dalam pendidikan anak usia dini di RA Team Cendekia Surabaya. ${ }^{4}$

Persamaan dari dua penelitian diatas dengan penelitian yang akan peneliti lakukan adalah sama-sama membahas tentang peran orang tua dalam mendampingi pembelajaran saat pandemi sedangkan perbedaannya adalah penelitian yang pertama membahas tentang peran orang tua dalam menerapkan pembelajaran di rumah saat pandemi covid-19 yang difokuskan untuk anak usia 5-8 tahun saja dengan menggunakan pendekatan studi fenomenologi, penelitian kedua membahas tentang peran orang tua yang dilaksanakan untuk mendukung kegiatan pembelajaran pada pendidikan anak usia dini di RA team cendekia Surabaya, sedangkan penelitian yang akan peneliti lakukan adalah untuk mengetahui bagaimana gambaran kondisi orang tua yang kurang memahami teknologi dan minim wawasan dalam mendampingi belajar anak serta bagaimana peran orang tua dalam mendampingi belajar anaknya di masa pandemi covid-19 kelas 1-3 MI Mambaul Ulum Pakandangan di masa pandemi covid-19 ini dengan pendekatan studi kasus.

Adapun tujuan penelitian ini untuk mengetahui bagaimana gambaran kondisi orang tua yang kurang memahami teknologi dalam mendampingi belajar anak di masa pandemi serta bagaimana peran orang tua dalam pendampingan belajar anak di masa pandemi covid-

\footnotetext{
${ }^{4}$ Agustien Lilawati, "Peran Orang Tua Dalam Mendukung Kegiatan Pembelajaran Di Rumah Pada Masa Pandemi," Jurnal Pendidikan Anak Usia Dini 05 (2021): 549.
} 
19, studi kasus pada orang tua anak kelas 1-3 MI Mambaul Ulum desa Pakandangan Tengah.

\section{METODE PENELITIAN}

Dalam penelitian ini peneliti menggunakan metode penelitian kualitatif, dengan pendekatan studi kasus. Jenis penelitian ini adalah jenis penelitian deskriptif yang merupakan bagian dari karakteristik penelitian kualitatif. Sumber data dari penelitian ini adalah sumber data primer dan sekunder. Sumber data primernya adalah wawancara dengan 5 orang tua pada anak kelas 1-3 MI Mambaul Ulum desa Pakandangan Tengah. Sedangkan data sekunder bisa diperoleh dari observasi dan dokumentasi.

Teknik pengambilan sumber data atau informan dalam penelitian ini adalah dengan menggunakan teknik purposive sampling yaitu teknik ini dilakukan dengan pengambilan sumber data melalui pertimbangan terlebih dahulu, ${ }^{5}$ yakni sumber data dianggap paling tahu tentang apa yang berhubungan dengan penelitian di atas, sehingga mempermudah peneliti untuk lebih dalam mempelajari dan mendalami obyek dan situasi dari penelitian tersebut.

Analisis data yang digunakan dalam penelitian ini adalah model Miles dan Huberman, yaitu Reduksi data (data reduction), penyajian data (data display) dan penarikan kesimpulan (conclusion drawing/ verification). ${ }^{6}$ Kemudian pengecekan keabsahan data yang digunakan dalam penelitian ini adalah Triangulasi yaitu dengan menggabungkan sumber data yang ada. Dimana dalam penelitian ini, triangulasi yang digunakan adalah triangulasi dengan sumber data.

\footnotetext{
${ }^{5}$ Sugiono, Metode Penelitian Kuantitatif, Kualitatif Dan $R \& D$ (Bandung: Alfabeta, 2017), 85.

${ }^{6}$ Ibid., 246.
} 


\section{HASIL DAN PEMBAHASAN}

Pada hakikatnya belajar dan pembelajaran adalah suatu kegiatan yang tidak dapat terpisahkan dari kehidupan manusia. Dengan belajar, manusia dapat mengembangkan potensi-potensi yang dimilikinya. Peran orang tua adalah mendampingi saat anak-anaknya melaksanakan pembelajaran online ini, paling tidak orang tua dapat memantau dan memastikan bahwa anak-anaknya mengikuti pembelajaran di rumah. Dan pendampingan tersebut merupakan motivasi psikis yang sangat berperan bagi anak-anaknya. Sisi positif yang lain dari para orang tua adalah mereka dapat lebih banyak menghabiskan waktu untuk membimbing perkembangan anak sambil belajar di rumah dan lebih banyak waktu untuk berkomunikasi dengan anak. Hal yang perlu diperhatikan yaitu agar guru dan orang tua dapat bekerja sama untuk menjaga semangat belajar pada anak. Orang tua berperan melakukan pendampingan belajar bagi anakanaknya, menyediakan sarana dan prasarana belajar serta memotivasi belajar anak. ${ }^{7}$ Orang tua juga berperan dalam penentuan masa depan anak-anaknya. Pendidikan seorang anak dimulai dari lingkungan keluarga yang menjadi hal penting dalam pembentukan karakter anak. Pendidikan di luar bukan berarti orang tua dapat begitu saja melepas anak-anaknya. Orang tua juga harus berperan untuk mengawasi dan mengarahkan pendidikan yang ditempuh anakanaknya. Selain itu, orang tua juga dapat mengetahui sampai dimana

\footnotetext{
${ }^{7}$ Oksiana Jatiningsih, "Peran Orang Tua Dalam Pemenuhan Hak Pendidikan Anak Pada Masa Belajar Dari Rumah,” Jurnal Ilmu Sosial dan Humaniora 10, no. 1 (2021): 156.
} 
kemampuan anak-anaknya dalam bidang pendidikan. ${ }^{8}$ Jadi, keterlibatan orang tua sangat penting karena memberikan pengaruh yang besar terhadap keberhasilan anak. ${ }^{9}$ Dengan demikian kita dapat mengambil kesimpulan sisi baik dari pembelajaran daring ini, baik bagi guru, orang tua, maupun anak.

\section{Gambaran Kondisi Orang Tua yang Kurang Memahami} Teknologi dan Minim Wawasan dalam Mendampingi Belajar Anak di Masa Pandemi Covid-19

Sejak terjadinya pandemi covid-19 pendidikan anak dilakukan dengan jarak jauh. Pembelajaran jarak jauh dilakukan dengan memanfaatkan teknologi yang ada sehingga anak dan orang tua tetap bisa berinteraksi dengan guru. Namun dalam implementasinya, pelaksanaan sistem pembelajaran ini tidak selalu berjalan dengan mulus. ${ }^{10}$ Kenyataannya masih banyak keluhan dari orang tua mengenai kesulitan mendampingi anak belajar di rumah karena belum paham caranya, tidak bisa menggunakan teknologi digital untuk pembelajaran anak, bahkan ada juga yang tidak memahami maksud pesan yang disampaikan oleh guru.

Selama pembelajaran di rumah banyak orang tua menganggap bahwa kendala yang dialami adalah anak sulit diajari, tidak fokus karena sebagian dari mereka hanya menganggap remeh, perhatian dari guru juga kurang bahkan untuk orang tua yang kurang

\footnotetext{
8 Zulfitria and dkk, "Pentingnya Peran Orang Tua Dalam Pendampingan Pembelajaran Daring Di Masa Pandemi Covid-19," in Prosiding Seminar Nasional Penelitian LPPM UMJ, 2020, 170.

9 Wiwin Yulianingsih, "Keterlibatan Orang Tua Dalam Pendampingan Belajar Anak Selama Masa Pandemi Covid 19," Jurnal Obsesi: Jurnal Pendidikan Anak Usia Dini 5, no. 2 (2021): 1141.

${ }^{10}$ Selfi Lailatul Iftitah and dkk, "Peran Orang Tua Dalam Mendampingi Anak Di Rumah Selama Pandemi Covid-19," JCE (Journal of Childhood Education) 4, no. 2 (2020).
} 
memahami teknologi sering kali mengalami kesulitan dalam mengawasi dan mengajari anaknya. Jadi untuk para orang tua yang kurang paham dalam hal teknologi selain memang harus mendampingi anak-anaknya juga harus sambil belajar, dan dampak yang dialami pada anak jadi kurang mendapat pengajaran. Bahkan menurut Riskiyah S. orang tua dari salah satu murid kelas 3 MI selama pembelajaran di rumah orang tualah yang membantu mengerjakan tugas yang diberikan oleh guru, walaupun ada juga yang merasa hal ini menjadi aktivitas tambahan selain mengerjakan pekerjaan aktivitas rumah.

Menurut Risqiyah ibu dari salah satu anak kelas 2 MI, selama pembelajaran di rumah guru lebih banyak memberikan tugas jadi untuk materi yang belum selesai tidak dijelaskan sehingga anak-anak banyak yang kurang memahami materinya. Banyak orang tua juga berpendapat bahwa pembelajaran di rumah anak-anak hanya merasa enteng dan menganggap remeh karena terbiasa bebas. Bahkan untuk mengerjakan tugas yang diberikan oleh guru pun terkadang masih harus dipaksa untuk mengerjakannya. ${ }^{11}$

Bagi orang tua yang kurang memahami teknologi pada saat pembelajaran daring, mereka hanya mendampingi sampai tugas yang diberikan guru kepada anaknya tuntas, selebihnya anak-anak dibantu kakak-kakaknya atau numpang kepada teman-temannya untuk mengumpulkan tugasnya melalui handphone dan aplikasi yang sudah ditentukan, begitupun menurut Khoiriyah salah satu orang tua dari anak-anak kelas $1 \mathrm{MI},{ }^{12}$ sedangkan menurut Zaifatur R. salah satu orang tua dari anak-anak kelas 2 MI Mambaul Ulum, orang tua

\footnotetext{
${ }^{11}$ Riskiyah S, "Orang Tua Membantu Mengerjakan Tugas Anak”, 11 Januari 2021

${ }^{12}$ Khoiriyah, "Dalam Pengumpulan Tugas Di Bantu Saudaranya Yang Lain," 2 January 2021.
} 
memang mendampingi anak pada saat belajar tetapi dalam pengumpulan tugasnya dibantu oleh saudaranya yang lain. ${ }^{13}$

Dengan adanya sistem pembelajaran di rumah di tengah pandemi ini menurut sebagian orang tua sangat merasa kesulitan karena orang tua yang kurang memahami teknologi jadi dalam mendampingi anak belajar di rumah menjadi kurang optimal. Orang tua yang kurang memahami teknologi tiba-tiba dituntut harus cepat beradaptasi dengan berbagai teknologi yang belum pernah dikenal sebelumnya. Jadi banyak orang yang merasa kebingungan. Di masa pandemi seperti sekarang ini, beradaptasi dengan teknologi itu sangat penting mengingat sebagian besar tugas sekolah atau kegiatan belajar mengajar harus melalui gawai/ gadget. Jadi sebagai orang tua harus bisa lebih aktif mempelajari fitur-fitur apa saja yang bisa membantu memfasilitasi anak dalam belajar.

\section{Peran Orang Tua dalam Pendampingan Belajar Anak di Masa}

\section{Pandemi Covid-19}

Kegiatan belajar di rumah dapat menjadi titik balik digalakkannya kembali peran keluarga, utamanya orang tua yang memang mempunyai peranan sangat penting dalam perkembangan anak. ${ }^{14}$ Jadi dengan adanya pembelajaran di rumah orang tua dapat memaksimalkan peran utamanya dalam mendidik anak-anaknya. Meskipun orang tua yang kurang memahami teknologi merasa kesulitan tetapi orang tua tetap mencoba untuk bersikap empati kepada anak-anak. Sebab di saat seperti ini kehadiran orang tualah

\footnotetext{
${ }^{13}$ Zaifatur R, "Dalam Pengumpulan Tugas Di Bantu Saudaranya Yang Lain," 2 January 2021.

${ }^{14}$ Iftitah and dkk, "Peran Orang Tua Dalam Mendampingi Anak Di Rumah Selama Pandemi Covid-19."
} 
yang mampu membuat anak lebih kuat dan tidak menyerah serta bisa memotivasi anak dalam belajar dan mampu berkomitmen untuk membuat perencanaan demi membantu anak belajar di rumah. Dengan begitu, orang tua tidak lagi merasa sulit mendampingi anak belajar di rumah.

Menurut Siska orang tua dari salah satu anak kelas 1 MI sebagai orang tua memang harus memberikan pengawasan yang ekstra selama pembelajaran berlangsung karena anak-anak cenderung tidak benar-benar fokus pada apa yang harus di pelajari banyak dari mereka masih ada yang sambil main game dan membuka aplikasi yang tidak ada hubungannya dengan pembelajaran tersebut. ${ }^{15}$

Peran orang tua dalam melakukan pendampingan kepada anak selama melaksanakan pembelajaran dari rumah memang sangat besar pengaruhnya terhadap keberhasilan program pembelajaran di tengah pandemi saat ini. Tanpa melibatkan orang tua, maka sekolah (guru) akan kesulitan dalam menyampaikan materi kepada siswa dan siswa juga akan merasa kesulitan dalam memahami materi yang disampaikan oleh guru jika tidak didampingi oleh orang tua. ${ }^{16}$ Adapun peran orang tua dalam mendampingi belajar anak di rumah yaitu:

\section{Orang tua sebagai pendamping}

Orang tua mendampingi anak belajar di rumah agar anak tidak merasa sendiri. Pendampingan yang dilakukan oleh orang tua membuat anak akan merasa nyaman dan membangkitkan rasa

\footnotetext{
${ }^{15}$ Siska, "Memberikan Pengawasan Yang Ekstra Selama Pembelajaran Di Rumah," 7 January 2021.

${ }^{16}$ Diah Rina Miftakhi and dkk, "Peranan Orang Tua Siswa Dalam Melaksanakan Pendampingan Pembelajaran Dari Rumah Secara Online," JOEAI: Journal of Education and Instruction 3, no. 2 (2020).
} 
percaya diri pada anak. Pendampingan belajar pada anak adalah hal yang harus dilakukan orang tua, dalam waktu cukup panjang harus belajar di rumah. Karena itu menjamin bahwa saatnya anak belajar melakukan aktivitas belajar merupakan hal yang sangat penting dilakukan setiap keluarga. ${ }^{17}$

Seperti menurut Risqiyah salah satu ibu dari murid kelas 2 MI, selama anak belajar orang tua mendampingi sampai tugas yang diberikan guru tuntas, tidak hanya itu orang tua juga menerangkan dan memberikan penjelasan mengenai materi yang belum di pahami oleh anak. Jadi dengan begitu anak merasa diperhatikan, dilindungi dan bisa meningkatkan rasa percaya diri pada anak.

\section{Orang tua sebagai motivator}

Tidak dapat dielakkan lagi bahwa belajar di rumah mengakibatkan kejenuhan bagi anak karena minimnya interaksi sosial dengan rekan-rekan sekolahnya. Di titik dimana anak mengalami kejenuhan akibat bosan belajar di rumah, motivasi sangat diperlukan bagi mereka untuk tetap eksis dalam proses kegiatan pembelajaran. Dalam keadaan ini orang tua dapat mengambil peran motivator dengan terus memberikan motivasi dan nasihat kepada anak untuk tetap antusias mengikuti pembelajaran daring. ${ }^{18}$ Orang tua dapat memberikan semangat kepada anak berupa kata-kata yang

\footnotetext{
17 Jatiningsih, "Peran Orang Tua Dalam Pemenuhan Hak Pendidikan Anak Pada Masa Belajar Dari Rumah," 151.

${ }^{18}$ Hadi Sultan Prabowo, "Peran Orang Tua Dalam Pembentukan Karakter Anak Di Masa Pandemi Covid-19 Perspektif Pendidikan Islam," Jurnal Pendidikan Islam 11, no. 2 (2020): 199-200.
} 
menimbulkan dorongan dalam diri anak sebagai pemacu semangat. Agar anak yang awalnya malas dalam belajar bisa bersemangat lagi. ${ }^{19}$

Menurut Siska dan Risqiyah salah satu ibu dari murid anak kelas 1-2 MI, agar anak-anaknya mematuhi dan nurut untuk diajari, orang tua memberikan nasihat yang bisa membuat anak-anaknya semangat lagi dalam belajar. Bahkan terkadang bagi anak yang tidak mau mendengarkan orang tua harus mengiming-imingi sesuatu yang disukai anak agar anak termotivasi dalam belajarnya.

\section{Orang tua sebagai fasilitator}

Fasilitator harus mampu mempengaruhi perubahan sikap sosial peserta didik dan memiliki peran memfasilitasi untuk belajar secara maksimal dengan mempergunakan berbagai strategi, metode, media dan sumber belajar. ${ }^{20}$ Orang tua dapat memfasilitasi kebutuhan anak untuk kegiatan belajarnya di rumah agar perkembangan anak tetap optimal. Pembelajaran dapat disesuaikan dengan apa yang telah di dapat di sekolah, agar tetap terjadi kesinambungan antara di rumah dan di sekolah. ${ }^{21}$ Mayoritas orang tua memberikan fasilitas yang dibutuhkan anak dalam belajar, seperti buku, alat tulis, gadget, kuota dan tempat yang nyaman untuk anak melakukan pembelajaran.

\section{Tempat berdiskusi dan bertanya}

Anak berinteraksi sosial pertama kali yaitu dengan orang tua. orang tua memiliki peran sebagai tempat diskusi ketika berada di rumah, anak akan cenderung terbuka dan mau memulai berdiskusi

\footnotetext{
${ }^{19}$ Iftitah and dkk, "Peran Orang Tua Dalam Mendampingi Anak Di Rumah Selama Pandemi Covid-19."

${ }^{20}$ Rani Mucharomah, "Peran Fasilitator Parenting Dalam Pengembangan Sosial Anak Usia Dini," Jurnal Pendidikan untuk Semua 2, no. 2 (2018): 9.

${ }^{21}$ Iftitah and dkk, "Peran Orang Tua Dalam Mendampingi Anak Di Rumah Selama Pandemi Covid-19," 78.
} 
dengan orang tua ketika diberikan waktu luang. ${ }^{22}$ Anak memiliki rasa ingin tau yang besar sehingga mereka akan bertanya apapun kepada orang tua. ${ }^{23}$ Seorang anak untuk memaksimalkan potensi yang dimilikinya membutuhkan seseorang untuk berdiskusi supaya bisa memberikan jawaban dan dapat memotivasi anak. Oleh karena itu, sangat penting untuk orang tua dapat memberikan waktu bersama anak untuk berdiskusi dan menjawab pertanyaan-pertanyaan dari anak.

\section{Menciptakan lingkungan yang kondusif untuk belajar}

Orang tua dapat menciptakan lingkungan dan suasana belajar yang nyaman sehingga anak dapat belajar dengan baik. ${ }^{24}$ Menurut Ibu Zaifatur R. orang tua tidak boleh emosi dalam mendampingi anaknya belajar. Orang tua harus bisa menciptakan suasana yang menarik dan menyenangkan agar suasana belajar anak berjalan secara alami dan anak tidak merasa terikat dan terkekang.

Kondisi pembelajaran yang kondusif hanya dapat dicapai jika interaksi sosial berlangsung secara baik. ${ }^{25}$ Pembelajaran di rumah pada masa pandemi covid-19 lebih mempererat hubungan orang tua dengan anak, orang tua dapat melihat perkembangan anak-anaknya dalam belajar. Jadi bisa disimpulkan bahwa di masa pandemi, seperti sekarang peran orang tua dalam optimalisasi proses belajar anak akan menjadi ujung tombak keberhasilan belajar anak, baik proses

\footnotetext{
${ }^{22}$ Gilang Fathurochman, "Peran Orang Tua Dalam Pembelajaran Jarak Jauh Anak Tunagrahita," Jurna Pendidikan Khusus 16, no. 1 (2020): 482.

${ }^{23}$ Iftitah and dkk, "Peran Orang Tua Dalam Mendampingi Anak Di Rumah Selama Pandemi Covid-19," 79.

${ }^{24}$ Ibid.

${ }^{25}$ Arianti Arianti, "Urgensi Lingkungan Belajar Yang Kondusif Dalam Mendorong Siswa Belajar Aktif," Didaktika Jurnal Kependidikan 11, no. 1 (2017): 43.
} 
pengembangan komunikasi bahkan sampai pengetahuan akademik anak.

\section{KESIMPULAN}

Peran orang tua memang sangat diperlukan untuk proses pembelajaran di rumah selama masa pandemi covid-19, apalagi anakanak yang belum memahami tentang wabah ini jadi orang tua memang harus memberikan edukasi terhadap anak agar tidak keluar rumah untuk mencegah penularan virus ini. Orang tua yang kurang memahami teknologi merasa kesulitan dalam mendampingi belajar anak di masa pandemi covid-19 karena beberapa faktor salah satunya yaitu tidak bisa menggunakan teknologi digital sehingga dalam pendampingan tersebut menjadi kurang optimal.

Meskipun orang tua yang kurang memahami teknologi merasa kesulitan tetapi orang tua tetap mencoba untuk bersikap empati kepada anak-anak. Sebab di saat seperti ini kehadiran orang tualah yang mampu membuat anak lebih kuat dan tidak menyerah serta bisa memotivasi anak dalam belajar. Adapun peran orang tua dalam mendampingi belajar anak yaitu, orang tua sebagai pendamping, sebagai motivator, fasilitator, menjadi tempat berdiskusi dan bertanya serta dapat menciptakan tempat yang kondusif dan nyaman untuk belajar. Sehingga peran orang tua khususnya pada sistem pembelajaran jarak jauh pada masa pandemi sangat berpengaruh dalam mencapai keberhasilan belajar anak.

\section{DAFTAR PUSTAKA}

Arianti, Arianti. "Urgensi Lingkungan Belajar yang Kondusif dalam Mendorong Siswa Belajar Aktif." Didaktika Jurnal Kependidikan 11, no. 1 (2017). 
Cahyati, Nika, and Rita Kusumah. "Peran Orang Tua dalam Menerapkan Pembelajaran di Rumah Saat Pandemic Covid 19." Jurnal Golden Age Universitas Hamzanwadi 4 (2020).

Fathurochman, Gilang. "Peran Orang Tua dalam Pembelajaran Jarak Jauh Anak Tunagrahita." Jurna Pendidikan Khusus 16, no. 1 (2020).

Iftitah, Selfi Lailatul, and dkk. "Peran Orang Tua dalam Mendampingi Anak di Rumah Selama Pandemi Covid-19." JCE (Journal of Childhood Education) 4, no. 2 (2020).

Jatiningsih, Oksiana. "Peran Orang Tua dalam Pemenuhan Hak Pendidikan Anak pada Masa Belajar dari Rumah.” Jurnal Ilmu Sosial dan Humaniora 10, no. 1 (2021).

Kurniawati, Euis, and dkk. "Analisis Peran Orang Tua dalam Mendampingi Anak di Masa Pandemi Covid 19." Jurnal Pendidikan Anak Usia Dini 5 (2021).

Lilawati, Agustien. "Peran Orang Tua dalam Mendukung Kegiatan Pembelajaran di Rumah pada Masa Pandemi." Jurnal Pendidikan Anak Usia Dini 05 (2021).

Miftakhi, Diah Rina, and dkk. "Peranan Orang Tua Siswa dalam Melaksanakan Pendampingan Pembelajaran dari Rumah Secara Online." JOEAI: Journal of Education and Instruction 3, no. 2 (2020).

Mucharomah, Rani. "Peran Fasilitator Parenting dalam Pengembangan Sosial Anak Usia Dini." Jurnal Pendidikan untuk Seтua 2, no. 2 (2018).

Prabowo, Hadi Sultan. "Peran Orang Tua dalam Pembentukan Karakter Anak di Masa Pandemi Covid-19 Perspektif Pendidikan Islam.” Jurnal Pendidikan Islam 11, no. 2 (2020).

Sudarsa, Ketut, and dkk. "Covid-19: Perspektif Pendidikan Yayasan." Kita Menulis.

Sugiono. Metode Penelitian Kuantitatif, Kualitatif dan R\&D. Bandung: Alfabeta, 2017.

Yulianingsih, Wiwin. "Keterlibatan Orang Tua dalam Pendampingan Belajar Anak Selama Masa Pandemi Covid 19.” Jurnal Obsesi: Jurnal Pendidikan Anak Usia Dini 5, no. 2 (2021).

Zulfitria, and dkk. "Pentingnya Peran Orang Tua dalam Pendampingan Pembelajaran Daring di Masa Pandemi Covid19." In Prosiding Seminar Nasional Penelitian LPPM UMJ, 2020. 
Novita Afkarina, Fayruzah El-Faradis | MAHAROT Vol. 5, No. 1, 2021 